\title{
Corporate Governance Mechanisms and Capital Structure Decision of Textile Companies in Bangladesh
}

\author{
Md. Alaul Haque \\ Md. Alaul Haque, Senior Lecturer, Metropolitan University, Sylhet \\ Sobhana Tanzima Atiq* \\ Assistant Professor, Shahjalal University of Science and Technology, Sylhet \\ Dr. Mohammad Shahidul Hoque \\ Professor, Shahjalal University of Science and Technology, Sylhet
}

\begin{abstract}
Purpose: The purpose of this study is to examine the impact of corporate governance mechanisms on capital structure decisions of Textile Companies in Bangladesh. In particular, the paper examines the degree to which internal corporate governance mechanisms and an external corporate governance mechanism affect Bangladeshi textile firms' capital structure.

Methodology of the Study: The paper uses a multiple regression analysis to examine the effect of corporate governance and capital structure for a sample of 10 Bangladeshi textile firms listed in DSE during period from 2011 to 2017.Board size, Board composition, Board meetings \& Board ownership were used as corporate governance variables and Return on Assets (ROA) also used as control variable and debt ratio used as the measure of capital structure. This study also used different statistical tools like descriptive statistics, Pearson correlation and multiple regressions.

Findings: The findings indicate that the relationship of Debt Ratio with Board Size \& Board Composition is positive and highly significant, a less significant or moderate positive relationship between Debt Ratio \& Board Ownership, insignificant and negative relationship between Debt Ratio \& Board Meetings and the Debt Ratio is negatively related to Return on Assets that is significant.CG mechanisms (Board Size \& Board Ownership) are significantly and positively impact on firms Capital Structure/ Debt Ratio (DR) and (Board Composition \& Board Meetings) are also positively impact on firms Capital Structure but that is statistically insignificant and Return on Assets is highly significant \& negatively impact on firms Capital Structure/ Debt Ratio (DR) of Listed Textile Companies in Bangladesh.
\end{abstract}

[Keywords: Corporate Governance (CG), Capital Structure (CS), Debt Ratio (DR)]

DOI: $10.7176 / \mathrm{JESD} / 10-20-02$

Publication date:October $31^{\text {st }} 2019$

\section{Introduction}

Corporate governance has turn into an international issue due to globalization of businesses. Since the early 1990s, collapses of big financial institutions such as Barings Bank in 1995, Enron in 2001, Royal Ahold in 2003, had opened the door of thinking about the CG practices in business organizations (Ullah,2009). There is no worldwide accepted set of CG principles that can be used to board structures, as CG depend on education, economic environment and business practices of the countries. Developing countries CG practice differs compared to developed countries CG practice in a wide variety of ways. Thus, it is necessary for developing countries to build up their own corporate governance models according to their political, cultural, educational and technological conditions (Mulili \& Wong, 2011). Recently, a great awareness among the researchers all over the world to carry out researches on CG and it contributes to the firms' competitive advantage and business success.

During the past few years, there has been a growing awareness of corporate governance in Bangladesh. As a consequence of that, it is now mandatory for companies to comply with the CG rules that formed part of the listing rules of the Dhaka Stock Exchange (DSE), which took effect from the February, 2006. Most of the investors are willing to invest their capital in which companies where good corporate governance is practiced (Sharoar, Zahirul, and Arafat, 2009). The present scenario of CG practices is not satisfactory in Bangladesh (Ullah, 2009).

The optimal mix of equity and debt financing decisions are very crucial to success of the companies (Graham \& Harvey, 2001). An earlier research on relationship between good CG and capital structure has been made in the developed countries, but a small number of studies have been carried out in the emerging countries (Ahmadpour et al. 2012).

Most of the Bangladeshi researcher's had made their studies focusing on firms' performance, firms' profitability and employees behavior. Few researchers have paid their attention to the CG practices scenario \& impact of corporate governance on firms' capital structure; even those studies also based on limited selected good CG variables and selected sample companies and most of the research findings are contradictory. 
Thus, a minuscule research in this area has induced the need for this study. Furthermore, this study attempts to fill a gap in the literature by illuminating the significant links between corporate governance \& capital structure of firms and the Effect of Corporate Governance mechanisms on Firm's Capital Structure that is Selected Listed Textile Companies in Bangladesh.

\section{Literature Review and Hypotheses}

Corporate Governance: Corporate governance as "the system by which companies are directed and controlled" Cadbury (1992). According to Keong (2002), good corporate governance brings better management and prudent allocation of the company's resources, and enhances corporate performance which would significantly contribute to the company's share price, increasing the value of a shareholder's holdings. The good CG helps to maintain effective internal control systems by creating accountability, responsibility, transparency in an organization. The importance of CG is extremely high in particularly less developed countries like Bangladesh because economic development and growth is highly dependent on a large extent of well functioning, stable and soundly managed corporate system. Before 2004 Bangladesh has no CG for companies.

The thinking on corporate governance in progress after 1990s and the issue of corporate governance came into light in the wake of stock market debacle in Bangladesh in 1996 by organizing seminars, conferences and discussion by Organization for Economic Co-operation and Development (OECD), SEC and other scholars of corporate culture (Talukdar, 2007).In March 2004, Bangladesh Enterprise Institute introduces the code of good CG for Bangladesh and after the two years in February 2006 the Securities and Exchange Commission (SEC) issued a notification and by this notification the SEC imposes condition 'comply or explain' to all companies listed in any stock exchange of Bangladesh. Though the good corporate governance practices are gradually increasing in Bangladesh, but it is till now in initial stage.

\section{Corporate Governance and Capital Structure}

The capital structure decision is a vital one since the profitability of a company is directly affected by such decision in Srilankan Listed Manufacturing Companies (Kajanathan, 2012). Velnampy \& Aloy (2012) said that one of the key elements of the firms' financial strategy is a successful selection of sources of capital fund and the use of capital in productive sector. The solvency of a company is largely depends on the CS of a company. According to Velnampy (2006), "the financial condition of a business organization would depend on the resources it owns and the obligations it has to meet. In addition to that Claessens et al. (2001) argue that good corporate governance mechanisms help firms through a better access to financing and a lower cost of capital. Kajanathan (2012) found his study that corporate governance practices had 34\% impact on the capital structure of Sri Lankan listed manufacturing companies and among corporate governance variables. Brenni (2014) also found the same result in UK Real Estate Companies. However, Peiris and Fernando (2013) found nonfinancial companies in Sri Lanka that CG characteristics have no significant effect on the capital structure decisions. Similar to that, Ravivathan \& Danoshand, (2014) also stated that good corporate governance characteristics have no significant impact on the capital structure.

The association between board size and capital structure is mixed in past research studied. Hasan \& Butt (2009); Bodaghi \& Ahmadpour (2010); Vakilifard et al. (2011) and Magdalena (2012) found a significant negative association between board size and debt-to-equity ratio. It stated that those firms have a large board of directors generally they have low debt-equity ratios. But Kajanathan (2012) and Wellalage \& Locke (2012) found out their study that a positive relationship between the board size and debt ratios. Appuhami and Bhuyan (2015) also found the same result in top service firms in Australia. The relationship between non-executive directors' in the board and firm leverage ratio is mixed in past research. Abor (2007), Sheikh \& Wang (2012) and Kajanathan (2012), Appuhami and Bhuyan (2015) find a significant positive relationship between percentage of non-executive directors' in the board and firm leverage ratio. This indicates that outside directors have a positive impact on the corporate leverage. Kajanathan (2012), Non-executive directors ensures management accountability of shareholders and reduce agency conflicts between shareholders and managers which lead to having a high debt policy.

Appuhami and Bhuyan (2015) found that the relationship between Audit committee composition and CS is negative but Remuneration committee composition and CS is positive in top service firms in Australia. Kajanathan (2012) found a significant positive relationship between the number of board committees and capital structure in Sri Lankan manufacturing firms.

The evidence regarding relationship between the managerial ownership or board ownership and the CS also is mixed. According to Butt \& Hasan (2009) and Sheikh \& Wang (2012), they found out a negative relationship between the managerial ownership and the CS in Pakistan listed firms. But Wellalage \& Lock (2012), Sri Lankan listed companies have need of high debt policy with higher board ownership and CEO duality and recognized a significant positive relationship between board ownership percentage and leverage. Appuhami and Bhuyan (2015) also found significant positive impact on CS in firms in Australia. Siromi and Chandrapala (2017) profitability has 
a significant and negative impact on CS in Sri Lankan listed companies.

Board Size, Board Composition, Board Meeting, and Board Ownership were used as CG variables whereas debt ratio as the measure of CS and Return on Assets (ROA) as control variables.

\section{Research Hypothesis}

$\mathrm{HA}_{1}$ : There is a relationship between board size and capital structure (CS).

$\mathrm{HA}_{2}$ : Non-executive directors are associated with CS.

$\mathrm{HA}_{3}$ : Board ownership and capital structure has a relationship.

$\mathrm{HA}_{4}$ : Number of board meetings plays a positive role on capital structure.

$\mathrm{HA}_{5}$ : There is a relationship between Return on Asset and capital structure.

\section{Methodology of the Study}

In this study, design of the methodology was based on prior research into these relationships and to test the effect of CG practices on firms' CS. Pearson Correlation analysis were to examine the relationships between CG and CS for a sample of 10 Bangladeshi textile firms listed in DSE during period from 2011 to 2017. Board size, Board composition, Board meetings \& Board ownership were used as corporate governance variables and Return on Assets (ROA) also used as control variable and debt ratio used as the measure of capital structure. This study also used different statistical tools like descriptive statistics, correlation and multiple regressions.

Figure: 1.1 Conceptual Framework:

\begin{tabular}{|l|l|l|}
\hline Board size & & \\
\cline { 1 - 1 } Board composition & & Debt ratio (Capital Structure) \\
\cline { 1 - 1 } Board meeting & & \\
\hline Board ownership & & \\
\hline
\end{tabular}

Table- 2 Measurement of Variable

\begin{tabular}{|l|c|l|}
\hline \multicolumn{1}{|c|}{ Variables } & Symbols & \multicolumn{1}{c|}{ Measures } \\
\cline { 1 - 2 } Predictor Variables: & BS & Total number of members on the board \\
\hline Board Size & BC & $\begin{array}{l}\text { Proportion of outside directors on the board i.e. non- executive } \\
\text { directors in the board }\end{array}$ \\
\hline Board Composition & BO & Directors hold \% of shares of total outstanding share \\
\hline Board ownership & BM & Number of meeting hold in a year \\
\hline Return on assets & ROA & Profit before interest \& tax / Total assets \\
\hline Debt ratio & DR & Total debt / (Total debt + Equity) \\
\hline
\end{tabular}

\section{Sample Size:}

The sample size for this study was 10 listed companies 70 observations out of 53 listed textile companies that were listed at the period from 2011 to 2017 due to their nature of capital structure on Dhaka Stock Exchange. It covers $18.87 \%$ of the total population. The name of the companies were Anlimayarn Deying Ltd, Apex Spinning and Knitting Mills Ltd., Gesh Group, Envoy Textile Mills Ltd., Generation Next Ltd., Malek Spinnig Mills Ltd.,Rahim Textile Mills Ltd., Saiham Cotton Mills Ltd., Alhaj Textile Ltd. and Style Craft Ltd.

\section{Data Collection:}

Data was collected from annual reports submitted to the DSE, company website and Capital Markets Authority. The specific financial statements that were used in collecting the data were the income statement and the balance sheet and any supporting notes to the accounts. From the financial statements, the researchers collected information on debt level, shareholders equity, and numbers of directors, numbers of board meetings, total assets and board independent.

\section{Data analysis methods:}

The present study used descriptive statistics, Correlation and regression analysis. The descriptive statistics of mean, maximum and minimum were performed to identify the CG practices. Pearson Correlation measured the relationship between CG variables and CS. The linear-multiple regression analysis was used to test the effect of corporate governance on firm's capital structure. 
Data Analysis and Results:

Descriptive Analysis:

The descriptive statistics in this study show (Table: 3) average number of directors of the board in the listed companies is about 7 persons, The mean value of the board composition shows that non-executive directors to total directors of the board is 2, Board of Directors own average 39\% share, average number of board meeting of the listed textile companies in Bangladesh is 9 , average ROA is only $4.86 \%$. This indicates that the profitability of Bangladeshi textile firms is relatively poor during the test period with the respect to ROA. The debt ratio of the firms mean is $27.76 \%$ that suggests total debts are used only $27.76 \%$ of total capital and nearly about $73 \%$ of total assets are financed by equity capital of the sample firms in Bangladesh.

The mean value of selected CG characteristics show that majority of listed textile companies in Bangladesh are consist with the code of best practices on corporate governance (2004 \& 2006).

Table- 2: Descriptive Statistics

\begin{tabular}{|l|c|c|c|c|c|}
\hline & $\mathbf{N}$ & Minimum & Maximum & Mean & Std. Deviation \\
\hline Board Size & 70 & 4 & 10 & 6.77 & 1.534 \\
\hline Board Composition & 70 & 1 & 3 & 1.64 & .615 \\
\hline Board Ownership & 70 & .0796 & .8017 & .396021 & .2071032 \\
\hline Board Meeting & 70 & 4 & 26 & 9.04 & 4.282 \\
\hline Return on Assets & 70 & .0026 & .1651 & .048550 & .0309905 \\
\hline Debt Ratio & 66 & .0029 & .8119 & .277588 & .2035402 \\
\hline Valid N (list wise) & 66 & & & & \\
\hline
\end{tabular}

Pearson Correlation among variables:

The findings indicate that the relationship of Debt Ratio with Board Size \& Board Composition is positive and highly significant that means the relationship is very strong between them, significant and positive relationship between Debt Ratio \& Board Ownership that indicates the relationship are positive \& moderated, a insignificant and negative relationship Debt Ratio and Board Meetings it indicates the negative \& very low relationship and the Debt Ratio is negatively related to Return on Assets that is highly significant that indicates that highly significant very strong relationship.

Table - 4: Correlations among the variables

\begin{tabular}{|c|c|c|c|c|c|c|c|}
\hline \multicolumn{8}{|c|}{ Correlations } \\
\hline & & $\begin{array}{l}\text { Board } \\
\text { Size }\end{array}$ & $\begin{array}{c}\text { Board } \\
\text { Composition }\end{array}$ & $\begin{array}{c}\text { Board } \\
\text { Ownership }\end{array}$ & $\begin{array}{c}\text { Board } \\
\text { Meeting }\end{array}$ & $\begin{array}{l}\text { Return } \\
\text { on } \\
\text { Assets }\end{array}$ & $\begin{array}{l}\text { Debt } \\
\text { Ratio }\end{array}$ \\
\hline \multirow[t]{3}{*}{ Board Size } & $\begin{array}{l}\text { Pearson } \\
\text { Correlation }\end{array}$ & 1 & $.588^{* *}$ & -.137 & .010 & -.050 & $.544^{* 1 / 2}$ \\
\hline & Sig. (2-tailed) & & .000 & .260 & .932 & .682 & .000 \\
\hline & $\mathbf{N}$ & & 70 & 70 & 70 & 70 & 66 \\
\hline \multirow[t]{3}{*}{$\begin{array}{l}\text { Board } \\
\text { Composition }\end{array}$} & $\begin{array}{l}\text { Pearson } \\
\text { Correlation }\end{array}$ & & 1 & .220 & -.060 & .110 & $.470^{* 1+1}$ \\
\hline & Sig. (2-tailed) & & & .067 & .621 & .366 & .000 \\
\hline & $\mathbf{N}$ & & & 70 & 70 & 70 & 66 \\
\hline \multirow[t]{3}{*}{$\begin{array}{l}\text { Board } \\
\text { Ownership }\end{array}$} & $\begin{array}{l}\text { Pearson } \\
\text { Correlation }\end{array}$ & & & 1 & $-.328^{* * *}$ & .135 & .236 \\
\hline & Sig. (2-tailed) & & & & .006 & .264 & .056 \\
\hline & $\mathbf{N}$ & & & & 70 & 70 & 66 \\
\hline \multirow[t]{3}{*}{$\begin{array}{l}\text { Board } \\
\text { Meeting }\end{array}$} & $\begin{array}{l}\text { Pearson } \\
\text { Correlation }\end{array}$ & & & & 1 & .217 & -.185 \\
\hline & Sig. (2-tailed) & & & & & .071 & .138 \\
\hline & $\mathbf{N}$ & & & & & 70 & 66 \\
\hline \multirow[t]{3}{*}{$\begin{array}{l}\text { Return on } \\
\text { Assets }\end{array}$} & $\begin{array}{l}\text { Pearson } \\
\text { Correlation }\end{array}$ & & & & & 1 & -.303 \\
\hline & Sig. (2-tailed) & & & & & & .013 \\
\hline & $\mathbf{N}$ & & & & & & 66 \\
\hline \multirow[t]{3}{*}{ Debt Ratio } & $\begin{array}{l}\text { Pearson } \\
\text { Correlation } \\
\end{array}$ & & & & & & 1 \\
\hline & Sig. (2-tailed) & & & & & & \\
\hline & $\mathbf{N}$ & & & & & & \\
\hline \multicolumn{8}{|c|}{$* *$. Correlation is significant at the 0.01 level (2-tailed). } \\
\hline
\end{tabular}


Table: 5(a): Linear-Multiple Regression Analysis:

\begin{tabular}{|c|c|c|c|c|c|c|c|c|c|c|}
\hline & & & & Mo & Summary & & & & & \\
\hline Model & $\mathrm{R}$ & $\mathrm{R}$ & Adjusted & Std. & & Change & atist & & & Durbin- \\
\hline & & Square & $\begin{array}{c}\text { R } \\
\text { Square }\end{array}$ & $\begin{array}{c}\text { Error of } \\
\text { the } \\
\text { Estimate }\end{array}$ & $\begin{array}{c}\text { R Square } \\
\text { Change }\end{array}$ & $\begin{array}{c}\mathrm{F} \\
\text { Change }\end{array}$ & df1 & $\mathrm{df} 2$ & $\begin{array}{c}\text { Sig. F } \\
\text { Change }\end{array}$ & Watson \\
\hline 1 & $.695^{\mathrm{a}}$ & .483 & .440 & .1523321 & .483 & 11.209 & 5 & 60 & .000 & 1.222 \\
\hline
\end{tabular}

a. Predictors: (Constant), Board Size, Board Ownership, Board Meeting, Board Composition \& Return on Assets

b. Dependent Variable: Debt Ratio

The above table -5 (a) shows that $\mathrm{R}$ is multiple correlation coefficient and the value is 0.695 , while the $\mathrm{R}$ Square shows the ratio of interdependence and the value is 0.483 that means $48.3 \%$ variance of the dependent variable Debt Ratio is explained by the independent variables (Board Size, Board Ownership, Board Meeting, Board Composition \& Return on Assets).

Table: 5(b): ANOVA

\begin{tabular}{|l|l|c|c|c|c|c|}
\hline \multicolumn{2}{|c|}{ Model } & Sum of Squares & df & Mean Square & F & Sig. \\
\hline \multirow{5}{*}{} & Regression & 1.301 & 5 & .260 & 11.209 & $.000^{\text {b }}$ \\
\cline { 2 - 7 } & Residual & 1.392 & 60 & .023 & & \\
\cline { 2 - 7 } & Total & 2.693 & 65 & & & \\
\hline
\end{tabular}

a. Dependent Variable: Debt Ratio

b. Predictors: (Constant), Board Size, Board Ownership, Board Meeting, Board Composition, Return on Assets.

Table -5(b) shows that the ANOVA table is significant that indicates independent variables (Board Size, Board Ownership, Board Meeting, Board Composition \& Return on Assets) significantly predict the dependent variable (Debt Ratio). So it can be said that our model is fit for the study.

From Table- 5(c) Board Size \& Board Ownership has a highly positive impact on Capital Structure in Bangladeshi textile companies and highly significant that indicates those companies have large BS and percentages of BO are more they use more debt to others, the result is same as Vakilifard et. al (2011) in the Iranian Listed Firms. Board Meeting \& Board Composition has a positive and significant impact on Capital Structure in Bangladeshi textile companies. So it means that BM \& BC are not significant influential factor for using debt in Textile sector of Bangladesh. The impact of Return on Assets is highly negative and highly significant on Capital Structure in Bangladeshi textile companies that indicate those companies Return on Assets is high they use low debt.

At last we fit a regression equation Board Size, Board Ownership, Board Meeting, Board Composition \& Return on Assets as independent variables and Debt Ratio as dependent variable in the absence of other variables which can affect the Debt Ratio from table- 5(c).

$\mathrm{Y}=-0.228+0.062 \mathrm{BS}+0.045 \mathrm{BC}+0.292 \mathrm{BO}+0.000 \mathrm{BM}-2.145 \mathrm{ROA}+\mu$

Where, $\mathrm{Y}=$ Debt Ratio, $\mathrm{BS}=$ Board Size, $\mathrm{BC}=$ Board Composition, $\mathrm{BO}=$ Board Ownership, $\mathrm{BM}=$ Board Meeting, $\mathrm{ROA}=$ Return on Assets and $\mu=$ Error term

Table: 5(c)

\begin{tabular}{|c|c|c|c|c|c|c|}
\hline \multicolumn{7}{|c|}{ Coefficients $^{\mathrm{a}}$} \\
\hline \multirow[t]{2}{*}{ Model } & \multicolumn{2}{|c|}{$\begin{array}{c}\text { Unstandardized } \\
\text { Coefficients }\end{array}$} & $\begin{array}{l}\text { Standardized } \\
\text { Coefficients }\end{array}$ & \multirow[t]{2}{*}{$\mathrm{t}$} & \multirow[t]{2}{*}{ Sig. } & $\begin{array}{c}\text { Collinearity } \\
\text { Statistics }\end{array}$ \\
\hline & B & Std. Error & Beta & & & Tolerance \\
\hline (Constant) & -.228 & .116 & & -1.964 & .054 & \\
\hline Board Size & .062 & .018 & .464 & 3.396 & .001 & .462 \\
\hline Board Composition & .045 & .049 & .127 & .913 & .365 & .447 \\
\hline Board Ownership & .292 & .104 & .299 & 2.808 & .007 & .761 \\
\hline Board Meeting & .000 & .005 & -.003 & -.030 & .976 & .801 \\
\hline Return on Assets & -2.145 & .650 & -.329 & -3.302 & .002 & .866 \\
\hline
\end{tabular}


Table - 6: Hypothesis Testing based on significant:

\begin{tabular}{|l|l|c|c|c|}
\hline \multicolumn{1}{|c|}{ Hypothesis (Alternative) } & Results & $\mathbf{t}$ & $\mathbf{P}$ & Significant $(\mathbf{P}<\mathbf{t})$ \\
\hline $\begin{array}{l}\mathrm{HA}_{1} \text { There is a relationship between board size and capital } \\
\text { structure }\end{array}$ & Accepted & 3.396 & $\mathbf{. 0 0 1}$ & $\begin{array}{c}\text { Highly } \\
\text { Significant }\end{array}$ \\
\hline $\begin{array}{l}\mathrm{HA}_{2} \text { Outside directors on the board are related to capital } \\
\text { structure }\end{array}$ & Rejected & .913 & .365 & Insignificant \\
\hline $\mathrm{HA}_{3}$ Board-ownership and capital structure has relationship & Accepted & 2.808 & $\mathbf{. 0 0 7}$ & $\begin{array}{c}\text { Highly } \\
\text { Significant }\end{array}$ \\
\hline $\begin{array}{l}\mathrm{HA}_{4} \text { Number of board meetings plays a positive role on } \\
\text { capital structure. }\end{array}$ & Rejected & -.030 & .976 & $\begin{array}{c}\text { Highly } \\
\text { Insignificant }\end{array}$ \\
\hline $\begin{array}{l}\text { HA } \\
\text { capital structure }\end{array}$ & Accepted & - & $\mathbf{. 0 0 2}$ & $\begin{array}{c}\text { Highly } \\
\text { Significant }\end{array}$ \\
\hline
\end{tabular}

\section{Results}

The findings indicate that the relationship of Debt Ratio with BS \& BC is positive and highly significant, insignificant and positive relationship between DR \& BO, a less significant and negative relationship DR and BM and the DR is negatively related to ROA that is highly significant.

CG mechanisms (BS \& BO) are significantly and positively impact on firms CS/DR and (BC \& BM) are not significantly impact on firms CS/ DR of Listed Textile Companies in Bangladesh.

\section{Conclusion}

Based on the new capital structure theories, capital structure decisions can be affected by different factors, one of which most important is Corporate Governance.

From the first hypothesis that showed, there is a significantly positive relationship between board size and debt ratio and that indicates firms have large board size, have a higher level of Corporate Governance and have to use less amount of debt to reduce agency problems.

The results of the second hypothesis there is no significant relationship between Board Composition and capital structure. However, the expectation of findings was to exist a positive and significant relationship between $\mathrm{BC}$ and CS to decrease the agency problems based on the role of outside directors as independent people, also the result of Wen et al (2002), Berger et al (1997) and Abor (2007). The probable reasons for this inconsistency can be internal and external situational variables, such as: industry variation, life cycles different of firms, different countries, different methodologies in researches, and others. The other important reason can be that outside directors' is not being independent enough to implement their supervisory role.

The results of the third hypothesis there is a high significantly positive relationship between Board Ownership and debt ratio and that indicates firms have a higher level of Corporate Governance and large Board Ownership increase the debt and use less amount of debt to reduce agency problems.

The results of the forth hypothesis there is no positive significant relationship between Board Composition and capital structure. However, the expectation of findings was to exist a positive and significant relationship between $\mathrm{BM}$ and $\mathrm{CS}$ according to the past result of researcher

The results of the fifth hypothesis there is a strong negative relationship between ROA \& CS and that is statistically significant as well as ROA also negatively and significantly impact on CS. It indicates that those companies have more ROA they use less debt then the firms' lower ROA in sample firms in textile sector of Bangladesh, though the result would be positive because those firm's are more capable to use more debt. Here important findings that the more solvent firms are conservative to use debt $\&$ they prefer equity financing and low solvency firms are use more debt that is alarming for textile sector of Bangladesh because in future they will may insolvent.

The study only collected data from companies listed in DSE from 2011 to 2017 . This means that the study findings are skewed and only informs on the relationship between capital structure and the corporate governance of the Textile companies listed in DSE. However, the findings could be different in other companies which operate outside the DSE bracket such as CSE.

The study suffered the challenge of lack of data for some companies in some years. This largely affected the data collected by the researcher for the analysis by reducing the sample size of the observations of the study.

The study only collected data on the relationship between leverage and some aspects of corporate governance such as board size, board composition, Number of meetings, board ownership and ROA of the firm.

The other aspects of corporate governance such as gender representation, board diversity, age of the board members, and experience of the board members and ownership interest of the members have not been covered.

In future researcher may include their study large sample size and more CG variables like (CEO Duality, institutional ownership, foreign ownership, Committee composition, Independent Member in Audit committee, Number of Audit committee Meeting \& Independent Member in Remuneration committee) as well as use other 
Control Variables like (Company Age, Company Size, Return on equity, Audit committee size, Remuneration committee size, firms profitability \& firm value) then the result will be different and more generalize.

\section{Reference}

Abor, J. (2007). Corporate governance and financing decisions of Ghanaian listed firms. Corporate Governance: The international journal of business in society, 7(1), 83-92.

Appuhami, R., \& Bhuyan, M. (2015). Examining the influence of corporate governance on intellectual capital efficiency: Evidence from top service firms in Australia. Managerial Auditing Journal, 30(4/5), 347-372.

Berger, P. G., Ofek, E., \& Yermack, D. L. (1997). Managerial entrenchment and capital structure decisions. The journal of finance, 52(4), 1411-1438.

Bodaghi, A. and Ahmadpour, A. (2010). The Effect of Corporate Governance and Ownership Structure on Capital Structure of Iranian Listed Companies: $7^{\text {th }}$ International Conference on Enterprise Systems, Accounting and Logistics (7th ICESAL 2010) 28-29 June 2010, Rhodes Island, Greece.

Brenni, P. A. (2014). Corporate governance and Capital structure decisions of UK listed real estate companies. Corporate Governance, 5(1),42-54

Bulathsinhalage, S., \& Pathirawasam, C. (2017). The Effect of Corporate Governance on Firms' Capital Structure of Listed Companies in Sri Lanka. Journal of Competitiveness, 9(2).

Bulathsinhalage, S., \& Pathirawasam, C. (2017). The Effect of Corporate Governance on Firms' Capital Structure of Listed Companies in Sri Lanka. Journal of Competitiveness, 9(2).

Bulathsinhalage, S., \& Pathirawasam, C. (2017). The Effect of Corporate Governance on Firms' Capital Structure of Listed Companies in Sri Lanka. Journal of Competitiveness, 9(2).19 - 33, DOI: 10.7441/joc.2017.02.02

Butt, S. A., \& Hasan, A. (2009). Impact of ownership structure and corporate governance on capital structure of Pakistani listed companies. International Journal of Business \& Management, 4(2).50-57. Retrieved from: http:/ ssrn.com/abstract=1732511. www.ecsenet.org/journal.html.

Cadbury, A. (1992). Report of the Committee on the financial aspects of Corporate Governance, Gee \& Co. Ltd., London, United Kingdom.

Claessens, S. (2001). Corporate governance and development. Global Corporate Governance Forum 1, Focus o1. Retrieved from: www.gcgf.org.

Graham, J. R., \& Harvey, C. R. (2001). The theory and practice of corporate finance: evidence from the field. Journal of financial economics, 60(2-3), 187-243.

Kajananthan, R. (2012). Effect of Corporate Governance on Capital Structure, Case of the Sri Lankan Listed Manufacturing Companies. Journal of Arts. Sciences \& Commerce, vol:3 Issue-4(1), 63-71.

Keong, LC (ed.) 2002, Corporate Governance: An Asia-Pacific Critique, Sweet and Maxwell Asia, Hong Kong.

Magdalena, R. (2012). Influence of Corporate Governance on Capital Structure Decision: Evidence from Indonesian Capital Market. World Review of Business Research, 2(4), 37 - 49.

Mulili, M. B. and Wong, P. (2011). Corporate Governance Practices in Developing Countries, the Case in Kenya. International Journal of Business Administration, 2(1), 14-27. https:/ doi.org/10.5430/:jba.v2n1p14.

Peiris J. M. P. D. and Fernando S. P. K. (2013). The impact of corporate governance on capital structure decisions. First annual student's research symposium. Faculty of commerce \& management studies. University of Kelaniya, Sri Lanka., p36.

Ravivathani, T. \& Danoshana S. (2014). The impact of corporate governance practices on capital structure: Empirical study on the listed companies in Sri Lanka. Asia pacific journal of marketing and management review, 3(2).

Sharoar, Zahirul and Arafat (2009). Current status of the corporate governance guidelines in Bangladesh: A critical evaluation with legal aspect. Bangladesh Research Publications Journal, 3 (2), 971-981, Dhaka.

Sheikh, N.A.S. and Wang, Z. (2012). Effects of corporate governance on capital structure: empirical evidence from Pakistan. Corporate governance. The International journal of Business in society, Vol:12, Issue no:5, 629-641. http./ dx.doi.org/10.1108/14720701211275569.

Talukdar, M.B.U. (2007). Corporate governance: An essential mechanism to curb malpractices by organizations. Bangladesh Bank, Policy Analysis Unit (PAU), Research Department, Policy Note Series: PN-0801.

Ullah, M.M (2009). Corporate governance practices in Bangladesh: A case study on Trust Bank Limited. Southeast University Journal of Business Studies, V (2),P, Dhaka.

Vakilifard, H. R., Gerayli, M. S., Yanesari, A. M., \& Ma'atoofi, A. R. (2011). Effect of corporate governance on capital structure: Case of the Iranian listed firms. European Journal of Economics, Finance and Administrative Sciences, 35, 165-172. http://www.eurojournals.com

Velnampy. T, (2006). An empirical study on application of Altman original bankruptcy forecasting model in Sri Lankan companies. Journal of Management, Sai Ram Institute of Management, Vol:1(1). Retrieved from: http:/ hdi.handle.net/123456789/670.

Velnampy. T. and Aloy, Niresh. J. (2012), Corporate governance and performance. Global Journal of Management 
and Business Research, 12(13), 66-73.

Wellalage N H and Locke S (2012), "Corporate Governance and Capital Structure Decision of Sri Lankan Listed Firms", Global Review of Business and Economic Research, 8(1),157-169.

Wen, Y., Rwegasira, K., \& Bilderbeek, J. (2002). Corporate governance and capital structure decisions of the Chinese listed firms. Corporate Governance: An International Review, 10(2), 75-83. 